\title{
Epidemiological Characteristics of Trauma Patients Maxillofacial Surgery at the Hospital Geral de Blumenau SC From 2004 to 2009
}

\section{Aspectos Epidemiológicos dos Pacientes com Traumas Maxilofaciais Operados no Hospital Geral de Blumenau, SC de 2004 a 2009}

\author{
José Carlos Martins Junior*, Frederico Santos Keim**, Ernani Tiaraju de Santa Helena ***. \\ * Oral and Maxillofacial Surgeon, Hospital Santa Catarina and San Antonio de Blumenau - SC. Student, Medical University Regional Blumenau FURB \\ *** Medical Student FURB. \\ **** Professor. Doctor. \\ Institution: Regional University of Blumenau - FURB. \\ Blumenau / SC - Brazil. \\ Mail Address: Frederico Santos Keim Street - Victor Konder, 99 - Apto 601 - Bairro: Victor Konder - Blumenau / SC - Brazil - Zip code: 89010-000 - Telephone: \\ (+55 47) 9193-6583 - E-mail: kikosk@hotmail.com \\ Article received in February 11, 2010. Article accepted in March 26, 2010
}

\section{SUMMARY}

Introduction:

Accidents involving the face have increased incidence in the last four decades. The medical literature refers to the increase in motor vehicle collisions and urban violence as the major causes of injuries, especially in young individuals.

Objective: Raise the epidemiological profile of 222 patients with facial fractures at the Hospital Santo Antonio from 2004 to 2009

Method:

Case study with retrospective analysis of records of patients diagnosed with facial fractures. Several variables were considered: gender, age, occupation, education level, origin, location and number of bones involved, etiology, and mean hospital stay of patients.

Results:

The male sex predominated with 178 cases (80.1\%), the average age was 29.6 years, $86(38.73 \%)$ had a steady job. Unmarried 178 cases (80.18\%). Primary school predominated among the patients, 74 (33.34\%), and most live in the city of Blumenau, 175 (78.82\%). The assault was primarily responsible for the surgical indication in 79 cases (35.58\%), involving a bone in 193 cases (86.9\%). The main bone involved was the mandible in 90 cases (40.54\%). The average length of stay was 2.5 days.

Conclusions: The epidemiological profile of 222 patients is an individual male, aged 20-29 years old, unmarried, low education and employee. The most prevalent etiology was assault, involving a bone, the mandible being the most involved bone.

Keywords: epidemiology, maxillofacial injuries, bone fractures.

\section{RESUMO}

Introdução:

Objetivo:

Método:

Resultados:

Conclusão:

Palavras-chave:
Acidentes envolvendo a face apresentam incidência crescente nas últimas quatro décadas. A literatura médica faz referência ao aumento das colisões automobilísticas e à violência urbana, como as principais causas desses traumatismos, principalmente em indivíduos jovens.

Levantar o perfil epidemiológico de 222 pacientes de fraturas faciais do Hospital Santo Antônio de 2004 a 2009.

Estudo de casos com análise retrospectiva de prontuários de pacientes com diagnóstico de fratura facial. Foram consideradas as variáveis gênero, idade, profissão, grau de escolaridade, procedência, local e número de ossos envolvidos, etiologia e tempo médio de internação dos pacientes.

O sexo masculino predominou com 178 casos (80,1\%), a média de idade foi de 29,6 anos, 86 (38,73\%) tinham emprego fixo. Os solteiros 178 casos (80,18\%). Primeiro grau completo predominou entre os pacientes, $74(33,34 \%)$, e a maioria residia na cidade de Blumenau, 175 (78,82\%). A agressão física foi a principal responsável pela indicação cirúrgica com 79 casos $(35,58 \%)$, com envolvimento de um osso em 193 casos (86,9\%). O principal osso acometido foi a mandíbula com 90 casos (40,54\%). A média de tempo de internação foi de 2,5 dias.

O perfil epidemiológico dos 222 pacientes é: individuo masculino, na faixa etária de 20 a 29 anos, solteiro, com baixa escolaridade e empregado. A etiologia prevalente foi a agressão, com envolvimento de um osso, sendo a mandíbula o osso mais acometido.

epidemiologia, traumatismos maxilofaciais, fraturas ósseas. 


\section{INTRODUCTION}

The maxillofacial trauma can be considered a devastating aggression found in trauma centers because of the emotional consequences and the possibility of deformity, in addition to causing economic impact on a health system (1).

This is a trauma of a multidisciplinary approach, involving mainly the specialties of otolaryngology, ophthalmology, plastic surgery, maxillofacial and neurosurgery.

An assault not only involves maxillofacial soft tissue and bone but also, by extension, can affect the brain, eyes, sinuses and teeth.

The diagnosis and treatment of these lesions achieved great progress in recent years. The facial trauma has become an unavoidable issue for physicians due to the fact that its frequency is increasing, especially in the last four decades, associated with increased motor vehicle accidents and urban violence $(2,3)$.

Its etiology is heterogeneous and the predominance of one or another etiological factor is related to some characteristics of the population such as age, gender, social, urban and residential (4).

Studies show that men are more exposed to trauma due to the increased number of drivers of motor vehicles, for having the most contact sports, and have a social life more intense, therefore ingest more alcohol and other drugs $(1,2)$. But in the last three decades, there is a growing incidence of trauma in women, usually aged up to 40 years due to their greater participation in activities that were predominantly male $(5,6)$.

There are also reports in the literature that some population characteristics, such as living in rural and urban socio-economic or educational influence in the pathogenesis and severity of facial trauma $(4,7,8)$.

This study aims to understand the epidemiological profile of patients who underwent surgery for maxillofacial trauma in a general hospital in the city of Blumenau, SC.

\section{METHOD}

This research project was approved by the Ethics in Research at FURB, in the opinion no. 046/09.

From July 2004 to August 2009 were performed by one surgeon, 790 maxillofacial surgery at the Hospital Santo Antonio de Blumenau. The work was based on retrospective evaluation of records of patients diagnosed with facial fracture surgery in the same period.

This study included patients diagnosed with facial fractures and underwent emergency surgery or elective. The patients were from the Department of Maxillofacial Surgery, Hospital Santo Antonio Polyclinic or in Blumenau, SC.

Was used as an exclusion criterion, patients with facial trauma with only soft tissue involvement, those with simple fractures (linear) or dislocations that did not require referral to the surgical ward or were reduced in a bloodless himself in the emergency room.

Data collection was through the identification form, request for $\mathrm{AIH}$ (hospital admission), sheet evolution and surgical description. All surgeries were performed by one surgeon.

Among the information included: age (in years), sex, origin, marital status ( single, married, divorced, widowed and other), occupational status (self, student, employee, housewife, unemployed, retired and others), education ( incomplete or complete primary school, secondary school or incomplete, complete or incomplete higher and illiterate), anatomical fracture site (mandibular, zygomatic, zygomatic arch, maxilla, nasal, orbital and frontal), number of bones involved (from one to five bones), etiology of trauma and the mean length of stay in days.

The variables are presented in tables and graphs with absolute and relative frequency. For continuous variables, we calculated the average and its standard deviation and median.

\section{RESULTS}

We assessed 222 medical records of patients diagnosed with facial fractures. Most patients were male with 178 cases (80.1\%) aged between 1 and 60 years (Table 1).

Although the majority of patients, 175 of the total (78.82\%), being from the city of Blumenau, there is validity to neighboring cities as shown in (Table 1).

We also analyzed the marital status of surgical patients and found that unmarried individuals were more facial trauma that led to surgery, 148 in total, representing 66.6\%. Eighty-six individuals studied have permanent employment (38.7\%) (Table 1). 
We made a connection between schooling and facial trauma and found that most patients were operated on only the first grade, 133 in total (61.7\%) (Table 1).

As to etiology, in 79 patients (36\%) the main cause that led to surgery was physical aggression, followed by traffic accidents with 41 cases (19\%) and accidents involving motorcycle 27 (12\%) (Table 2).

Facial bones in order of involvement were the mandible, nasal bone and zygoma (Table 2), most involving only one bone (Table 2). The median length of hospital stay was 1 day.

Analyzing the etiology of age, we found that of all assaults, $72(91.1 \%)$ were in individuals over 18 years. Like all accidents, 81 (90\%) were in this same age group (Table 3).

As to education, we found that people with less education have suffered more injuries and accidents, respectively 48 (60.7\%) and 51 (56.6\%) (Table 4).

According to the etiology and the number of fractured bones per patient can be seen in our study that only patients with a fractured bone were the main cause aggression: 72 cases (91.1\%), while in patients with two or more fractured bones traffic accident was the most prevalent with 55 cases $75.3 \%$ (Table 5).

\section{DISCUSSION}

Regarding gender, studies show that the most affected is the male with the following results, $80.7 \%$ of 788 patients (7), 78\% of 164 (9) and $79.88 \%$ of 1024 patients (10) . Our results also showed male predominance with 178 cases $(80.1 \%)$.

In another study, we observed a higher prevalence of facial trauma in men (84.9\%), white $(82.7 \%)$ and the mean age was 29 years of 513 patients (11).

Our study showed the predominance of involvement of patients between 20-29 years, with 88 cases (38), and the smallest number of operated cases occurred in the age group $0-9$ years, 5 cases (2.5\%) and median ages was equal to 27 years.

There are studies showing that the most affected age group was 20-29 years, with approximately two thirds (69.8\%) of fractures occurred between ages 11-39 years (11). It coincides with our findings where we observed 84 patients (37.83\%) aged between 20 and 29 years.
Table I. Epidemiological profile of people who underwent surgery for facial fractures at the Hospital Santo Antonio in Blumenau, SC.

\begin{tabular}{|c|c|c|}
\hline Characteristics & $\mathrm{N}$ & $\%$ \\
\hline \multicolumn{3}{|l|}{ GENDER } \\
\hline Male & 178 & 80.10 \\
\hline Female & 44 & 9.90 \\
\hline \multicolumn{3}{|l|}{ AGE } \\
\hline $0-9$ years & 5 & 2 \\
\hline $10-19$ years & 37 & 17 \\
\hline $20-29$ years & 84 & 38 \\
\hline $30-39$ years & 48 & 22 \\
\hline $40-49$ years +50 years & 3810 & 174 \\
\hline \multicolumn{3}{|l|}{ MARITAL STATUS } \\
\hline Single & 148 & 66.66 \\
\hline Married & 38 & 17.11 \\
\hline Divorced & 17 & 7.65 \\
\hline Widowed & 3 & 1.35 \\
\hline Other & 16 & 7.20 \\
\hline \multicolumn{3}{|l|}{ SCHOOLING } \\
\hline First degree incomplete & 63 & 28.37 \\
\hline First degree complete & 74 & 33.33 \\
\hline 2nd degree incomplete & 33 & 14.86 \\
\hline 2nd degree complete & 42 & $|8.9|$ \\
\hline Incomplete higher & 2 & 0.90 \\
\hline Completetop & 3 & 1.35 \\
\hline Illiterate & 5 & 2.25 \\
\hline \multicolumn{3}{|l|}{ OCCUPATION } \\
\hline Standalone & 53 & 23.87 \\
\hline Student & 20 & 9.00 \\
\hline Employee & 86 & 38.73 \\
\hline Home & 8 & 3.60 \\
\hline Unemployed & 6 & 2.70 \\
\hline Retired & 2 & 0.90 \\
\hline Other & 5 & 2.25 \\
\hline No Information & 42 & $|8.9|$ \\
\hline \multicolumn{3}{|l|}{ ORIGIN } \\
\hline Blumenau & 175 & 78.82 \\
\hline Gaspar & | | & 4.95 \\
\hline Benedito Novo & 5 & 2.25 \\
\hline Pomerode & 6 & 2.70 \\
\hline Timbó & 7 & 3.15 \\
\hline Indaial & 8 & 3.60 \\
\hline Other & 10 & 4.50 \\
\hline
\end{tabular}

Source: Data collected from medical records, Hospital Santo Antonio - SC. 
Table 2. Profile of maxillofacial fractures at the Hospital Santo Antonio in Blumenau, SC.

\begin{tabular}{lrr}
\hline Characteristics & $N$ & $\%$ \\
\hline FRACTURED BONE & & \\
Jaw & 94 & 35.87 \\
Zygoma & 55 & 20.99 \\
Zygomaticarch & 11 & 4.19 \\
Maxis & 17 & 6.48 \\
Nasal & 60 & 22.90 \\
Orbit & 20 & 7.63 \\
Front & 5 & 1.90 \\
TOTAL & 262 & 100 \\
No. FRACTURES / PTEC & & \\
I bone & 194 & 87.38 \\
2 Bones & 21 & 9.45 \\
3 Bones & 3 & 1.35 \\
4 bones & 2 & 0.90 \\
5 bones & 2 & 0.90 \\
ETIOLOGY & & \\
Aggression & 79 & 35.58 \\
Automotive & 41 & 18.46 \\
Moto & 12.16 \\
Fall & 27 & 11.26 \\
Fracture sequelae & 25 & 3.15 \\
Cycling & 7 & 7.20 \\
Trampling & 16 & 2.70 \\
Sports & 6 & 3.60 \\
Firearm & 8 & 0.45 \\
Other & 12 & 5.40 \\
\hline Sor Dar & & \\
\hline
\end{tabular}

Source: Data collected from medical records, Hospital Santo Antonio - SC.
Chrcanovic BR et al. reported that most fractures occurred in adults aged 21-30 years (12).

In children and adults above 50 years, fractures were less frequent in our study. There were no surgical intervention in patients over 60 years.

There are studies that found that the low incidence of facial trauma in children and the elderly, due to the attention of family, stay at home and care of children and the characteristics of old age, as little activity social and sports activities, leaving little home and when they do they are accompanied $(13,14)$.

As to occupation, Montovani et al (2006) found a higher incidence in students (16.6\%) and masons (11.2\%). Our research shows that in 86 cases (38.73\%) patients had permanent employment, in 53 cases (23.87\%) were independent and 20 were students (9\%).

In our study we observed a greater prevalence of surgery for facial trauma in patients who had low education level (illiterate and primary school) 63\%. We assume that this had actually happened because the study was performed in hospital care with predominantly via the Unified Health System (SUS).

Profile of maxillofacial trauma is heterogeneous and the prevalence of etiologic factors is related to some characteristics of the population and the hospital studied, proven by our sample.

Table 3. Etiology by age.

\begin{tabular}{lccccc}
\hline ETIOLOGY & $0-18$ years & $>18$ years & Total & $\%$ 0- 18 & $\%>18$ years \\
& $N$ & $N$ & $N$ & & \\
\hline Aggression & 7 & 72 & 79 & $8.8 \%$ & $91.1 \%$ \\
Trafficaccident & 9 & 81 & 90 & $10 \%$ & $90 \%$ \\
Fall & 8 & 17 & 25 & $32 \%$ & $68 \%$ \\
Other & 3 & 13 & 16 & $18.7 \%$ & $81.2 \%$ \\
\hline
\end{tabular}

Source: Data collected from medical records of HSA - SC 2004-2009.

Excluded and ignored.

Table 4. Aetiology of schooling. I = illiterate or elementary school. 2 = high school or higher education

\begin{tabular}{lccccc}
\hline ETIOLOGY & Scholarity & Scholarity 2 & Total N & $\%$ I & $\% 2$ \\
\hline Aggression & 48 & 31 & 79 & $60.7 \%$ & $39.2 \%$ \\
Traffic accident & 51 & 39 & 90 & $56.6 \%$ & $43.3 \%$ \\
Fall & 20 & 5 & 25 & $80 \%$ & $20 \%$
\end{tabular}

Source: Data collected from medical records of HSA - SC 2004-2009.

Excluded and ignored. 
Table 5. Aetiology in the number of fractured bones.

\begin{tabular}{lcccc}
\hline ETIOLOGY & | fractured bone & 2 or + fractured bones & \% | | bone & $\%$ 2 bone or + \\
\hline Aggression & 72 & 7 & $91.1 \%$ & $8.8 \%$ \\
Trafficaccident & 55 & 18 & $75.3 \%$ & $24.6 \%$ \\
Fall & 25 & 0 & $100 \%$ & - \\
\hline
\end{tabular}

Source: Data collected from medical records of HSA - SC 2004-2009.

Excluded and ignored.

An accident involving the face have a rising incidence in the last four decades, the medical literature refers to the increase in motor vehicle collisions and urban violence as the main causes of these injuries, especially in young individuals $(2,3)$.

A recent study pointed to automobile accidents as still being the main cause of severe facial trauma (15). However these findings are justified due to work being carried out in a regional referral center for trauma, thus affecting the types of trauma that the hospital served as the severity of the patients.

Regarding the aetiology of facial trauma, Braustein PW (1957) studied accidents involving 2253 victims in 1000 and noted that $72.1 \%$ of injuries were caused by motor vehicles.

According Montovani et al (2006), among the most common causes, stood out automobile accidents (28.3\%), assaults (21\%) and accidental falls (19.5\%).

In the study of Wulkan et al (2005) with 164 patients, interpersonal violence was the most common cause overall (48.1\%), followed by fall (26.2\%). What confirms the tendency of most current studies to show an increased incidence of interpersonal violence, and suggest that this is the main etiology in facial trauma $(16,17)$. As was proven by our study, where we found a predominance of the etiology of aggression with 79 cases (35.5\%), followed by car accidents with 41 cases (18\%), bikes with 27 cases (12\%) and fall in 25 cases (11\%).

When the work correlate the etiology of facial trauma with age, we noticed in some studies that the main cause among people 0-19 years was the decrease $(17,18,19,20)$, another study found that both children (09 years) and adults older than 60 years the most common etiology was the fall, $46.8 \%$ and $40.7 \%$ respectively (11).

In our study, the same age (0-19 years) showed a prevalence of $19.4 \%$, however when we look at just the age group 0-9 years, we found a prevalence of falls as an etiological factor quite significant with $80 \%$. Some authors infer many factors that may favor for the fall will be significantly more frequent in older patients: the movement and balance are directly proportional to age, the conscience of the appearance of the face and its social importance increases with age (during a fall, children and adults considered to protect the face) (21).

Motor vehicle accidents were the leading cause of facial trauma in the age group 20-29 years (11). However, in this age group, we found a greater number of physical assault, 36 cases (42.8\%). Recent studies also show that in the age group 20 to 39 years, the main cause is the interpersonal violence, $55.5 \%(9,22,23)$, confirming our findings.

When correlated with the age of 40 years or more, WuLKan et al. (2005) noticed that the fall also the primary mechanism of fracture by trauma (62.6\%) that usually results from multiple causes pathological (eg osteoporosis).

Physiological mechanisms such as altered proprioception, weakness, tremor, and decreased reflexes facilitate the fall. Urinary tract infection and lung and alcohol use are also reported (22).

In our study we observed physical aggression being the main etiology in over 40 years, with 12 cases (25\%).

Regarding the type of fracture, in their case studies, Montovani et al. (2006) found 371 facial fractures simple a single fracture in the face - (72.3\%) 142 and multiple facial fractures (27.6\%). In our study we also found a higher prevalence of simple fractures, with 193 cases (86.93\%) according to the type of fracture, reported that the mandible was the most affected (35\%), followed by the zygoma (24\%) and nose (23\%).

Already ChrCanovic et al. (2004) reported after study of 1,326 facial fractures in 911 patients, more than the facial bone fractured was the mandible, followed by the zygomatic complex and nose.

The incidence in our study was, in descending order: jaw 94 cases (35.8\%), nose, 60 cases (22.9\%), zygomatic 55 cases (20.9\%), orbit 20 cases (7.6\%) and jaw in 17 cases (6.4\%).

A study of 2748 cases reported that in 1176 (42.7\%) patients had midfacial fractures and 512 (18.6\%) had 
fractures of the lower "jaw". Most patients with middle third facial fractures had zigomaticomaxilar region affected 422 (35.8\%), while the region parasinfisária fractures were the most common jaw 156 (30.4\%) (24).

Our study found 134 fractures of the facial middle third (57.51\%), 94 patients with involvement of the lower third (40.34\%) and 5 cases with involvement of the upper third (2.14\%).

The series of WuLKan M et al. (2005) involved a large extent, high-energy trauma, resulting in their most mandibular fractures (21.9\%), followed by Le Fort type fractures, facial or pan complex (17.8\%).

Montovani et al. (2006) correlated the single or isolated fractures of the attacks with low complexity, high complexity and fractures with motor vehicle accidents. The predominance in our study was to traumatic fractures isolated single or low-complexity, 193 cases $(86.93 \%)$.

Hagan EH, Huelke DF (1961) reported that 55.8\% of mandibular fractures were related to traffic accidents, $17 \%$ with physical aggression and $14 \%$ with other causes.

Rowe NL, KiLley HC (1968) reported that $11.6 \%$ of fractures of the mandible were related to automobile accidents, motorcycle 15.8\%, 18\% with physical aggression and $12 \%$, accidental falls.

We could relate the mandibular fractures and motorcycle accidents in 12 patients (12.76\%), car in 17 patients (18.08\%), assault in 36 (38.29\%), fall in seven surgical patients (7.44\%) and the remainder with various causes 22 (23.4\%).

\section{CONCLUSION}

We conclude that the epidemiological profile of 222 patients undergoing surgery for facial fractures performed by the specialty of maxillofacial traumatology at Hospital Santo Antonio in Blumenau, Santa Catarina 2004-2009 individual is male, aged 20-29 years old, single, low education and employee.

The most prevalent etiology was assault, involving only a fractured bone and the jaw bone most affected.

\section{Bibliographical RefERENCES}

1. Sastry SM, Sastry CM, Paul BK, Bain L, Champion HR.
Leading causes of facial trauma in the major trauma outcome study. Plast Reconstr Surg. 1995, 95:196-7.

2. Braustein PW. Medical aspects of automotive crash injury research. JAMA. 1957, 163:249-55.

3. Bull JP. Disabilities caused by road traffic accidents and their relations to severity. Acrid Anal Prev. 1985, 17:38797.

4. Larsen OD, Nielsen A. Mandibular fractures: An analysis of their etiology and location in 286 patients. Scand J Plast Reconstr Surg. 1976, 10:213.

5. Prince JD. Facial fractures and seat belts. Brit Dent J. 1983,155-12.

6. Osguthorpe DJ. Orbital wall fractures. Evolution and management. Otolaryngol Head and Neck Surg. 1991, 105:702-7.

7. Sherer M, Sullivan WG, Smith DJ et al. An analysis of 1423 facial fractures in 788 patients at an urban trauma center. J Trauma. 1989, 29:388-90.

8. Busuito MJ, Smith DJ, Robson MC. Mandibular fractures in an urban trauma center. J Trauma. 1986, 26:826-9.

9. Wulkan M et al. Epidemiologia do Trauma Facial. Rev Assoc Med Bras. 2005, 51(5):290-5.

10. Brasileiro B, and Passeri L. Epidemiological analysis of maxillofacial fractures in Brazil: A 5-year prospective studyOral Surg Oral Med Oral Pathol Oral Radiol Endod. 2006, 102:28-34.

11. Montovani et al. Etiologia e incidência das fraturas faciais em adultos e crianças: experiência em 513 Casos. Rev Bras Otorrinolaringol. 2006, 72(2):235-41.

12. Chrcanovic BR et al. Facial fractures: a 1-year retrospective study in a hospital in Belo Horizonte. Braz Oral Res. 2004, 18(4):322-8.

13. Posnick JC. Pediatric facial fractures. Ann Plast Surg. 1994, 33:442-57.

14. Lucht UA. A prospective study of accidental falls and resulting injuries in the home among elderly people. Acta Soc Med Scand. 1971, 2:105-9.

15. Shapiro AJ, Johnson RM, Miller SF, McCarthy MC. Facial fractures in a level I trauma centre: the importance of protective devices and alcohol abuse. Injury. 2001, 32:3536. 
16. Beck RA, Blakeslee DB. The changing picture of facial fractures. Arch Otolaryngol Head Neck Surg. 1989, 115:8269.

17. Haug RH, Prather J, Indresano AT. An epidemiologic survey of facial fractures and concomitant injuries. J Oral Maxillofac Surg. 1990, 48:926-32.

18. Shaikh ZS, Worrall SF. Epidemiology of facial trauma in a sample of patients aged 1-18 years. Injury. 2002, 33:669-71.

19. Tanaka N, Uchide N, Suzuki K. Maxillofacial injuries in children. J Craniomaxillofac Surg. 1993, 21:289-93.

20. Zerfowski M, Bremerich A. Facial trauma in children and adolescents. Clin Oral Invest. 1998, 2:120-4.

21. Haugh RH, Foss J. Maxillofacial injuries in the paediatric patient. Oral Surg Oral Med Oral Pathol Oral Radiol Endod. 2000, 90:126-34.
22. Hussain K, Don BW. A comprehensive analysis of cranifacial trauma. J Trauma. 1994, 36:34-47.

23. Keenan HT, Brundage SI, Thompson DC. Does the face protect the brain?A case-control study for traumatic brain injury and facial fractures. Arch Surg. 1999, 134:14-7.

24. Subhashraj K, et al.- Review of maxillofacial injuries in Chennai,India: A study of 2748 cases. British Journal of Oral and Maxillofacial Surgery. 2007, 45:637-639.

25. Hagan EH, Huelke DF. An analysis of 319 case reports of mandibular fractures. J Oral Surg Anest Hosp Dent Serv. 1961, 19:93-104.

26. Rowe NL, Killey HC. Fractures of the facial skeleton. Baltimore: Willians \& Wilkins Co; 1968. 